\title{
Cerebral monitors versus regional anesthesia to detect cerebral ischemia in patients undergoing carotid endarterectomy: a meta-analysis
}

\section{Comparaison des moniteurs cérébraux et de l'anesthésie régionale pour dépister l'ischémie cérébrale chez les patients subissant une endartériectomie carotidienne: une méta-analyse}

\author{
Joanne Guay, MD · Sandra Kopp, MD \\ Received: 27 June 2012/Accepted: 18 December 2012/Published online: 6 February 2013 \\ (C) Canadian Anesthesiologists' Society 2013
}

\begin{abstract}
Purpose The aim of this meta-analysis is to compare the ability of different types of brain monitoring systems vs clinical monitoring of the brain function to detect cerebral ischemia during cross-clamping of the carotid artery under regional anesthesia.

Methods In May 2012, a search was conducted in PubMed, Cochrane Central Register of Controlled Trials, Cochrane Database of Systematic Reviews, and Ovid $M E D L I N E^{\circledR}$ for prospective trials with 20 patients or more where a cerebral monitoring system was compared with clinical brain monitoring during a carotid endarterectomy performed under regional anesthesia. The quality of the study was evaluated with the Cochrane Collaboration's tool. Data were extracted independently by the two investigators.
\end{abstract}

Results Data could be extracted for 4,664 measurements taken from 29 studies: transcranial Doppler $(T C D)=739$;

\footnotetext{
Author contributions Joanne Guay and Sandra Kopp were involved in the conception and design of the study and the acquisition and interpretation of the data. Joanne Guay analyzed the data and drafted the article, and Sandra Kopp revised the article critically for important intellectual content.
}

Electronic supplementary material The online version of this article (doi:10.1007/s12630-012-9876-4) contains supplementary material, which is available to authorized users.

\section{J. Guay, MD ( $\varangle)$}

Department of Anesthesiology, University of Montreal,

Montreal, QC, Canada

e-mail: joanneguay@bell.net

S. Kopp, MD

Department of Anesthesiology, Mayo Clinic College of

Medicine, Rochester, MN, USA cerebral saturation $=320 ; \quad$ stump pressure $=2,549$; electroencephalography $(E E G)=742 ;$ evoked potentials $=187 ;$ jugular venous saturation $=79 ;$ and jugular venous lactate $=48$. The pooled diagnostic odds ratios (DOR) and 95\% confidence intervals (CI) were obtained for EEG, TCD, stump pressure, evoked potentials, and cerebral saturation: (DOR 65.3; 95\% CI 20.5 to $207.7 ; I^{2}$ [56.8\%]); (DOR 58.1; 95\% CI 23.0 to $146.3 ; I^{2}$ [24.9\%]); (DOR 27.8; 95\% CI 13.4 to 57.9; I I [59.9]); (DOR 17.2; 95\% CI 2.4 to $123.9 I^{2}$ [69.1]); and (DOR 12.1; $95 \% \mathrm{CI}$ 3.5 to 41.2; $I^{2}$ [30.8]), respectively. Sequential testing with stump pressure $25 \mathrm{mmHg}$ followed by either TCD or EEG delivered the best post-test probabilities. For EEG, the DOR increases with the number of channels used $(P=0.03)$.

Conclusion A combination of stump pressure and either TCD or EEG appears to deliver the best results for detecting brain ischemia during carotid artery crossclamping. Electroencephalography should be used with a high number of channels.

\section{Résumé}

Objectif L'objectif de cette méta-analyse est de comparer la capacité de différents types de systèmes de monitorage cérébral par rapport au monitorage clinique de la fonction cérébrale pour dépister l'ischémie cérébrale pendant le clampage de l'artère carotidienne sous anesthésie régionale. Méthode En mai 2012, une recherche a étémenée dans les bases de données PubMed, le registre central d'études contrôlées Cochrane (Cochrane Central Register of Controlled Trials), la base de données de revues méthodiques Cochrane (Cochrane Database of Systematic Reviews) et Ovid MEDLINE ${ }^{\circledR}$ afin d'en tirer les études prospectives portant sur 20 patients ou plus et comparant un système de 
monitorage cérébral à un monitorage cérebral clinique pendant une endartériectomie carotidienne réalisée sous anesthésie régionale. La qualité des études a été évaluée avec l'outil de collaboration Cochrane. Les données ont été récupérées de façon indépendante par deux chercheurs.

Résultats Des données ont pu être récupérées pour 4664 mesures tirées de 29 études: Doppler transcrânien $(T C D)=739 ; \quad$ saturation $\quad$ cérébrale $=320 ; \quad$ pression résiduelle carotidienne $=2549$; électroencéphalographie $(E E G)=742 ; \quad$ potentiels évoqués $=187 ; \quad$ saturation veineuse jugulaire $=79$; et lactate veineux jugulaire $=$ 48. Les rapports de cotes diagnostiques (RCD) totalisés et les intervalles de confiance (IC) à $95 \%$ ont été obtenus pour l'EEG, le TCD, la pression résiduelle carotidienne, les potentiels évoqués et la saturation cérébrale: (RCD 65,3; IC 95 \% 20,5 à 207,7; $I^{2}$ [56,8 \%]); (RCD 58,1; IC $95 \%$ 23,0 à 146,3; $\left.I^{2}[24,9 \%]\right) ;(R C D$ 27,8; IC $95 \%$ 13,4 à 57,9; $\left.I^{2}[59,9]\right) ;\left(R C D\right.$ 17,2; CI $95 \% 2,4$ à 123,9; $I^{2}$ [69,1]); et (RCD 12,1; IC $95 \%$ 3,5 à 41,2; $I^{2}$ [30.8]), respectivement. Les tests séquentiels avec $25 \mathrm{mmHg}$ de pression résiduelle carotidienne suivis soit d'un TCD ou d'une EEG ont donné les meilleures probabilités post-test. Pour l'EEG, les RCD augmentent avec le nombre de canaux utilisés $(P=0,03)$.

Conclusion Une combinaison de pression résiduelle carotidienne et de TCD ou d'EEG semble donner les meilleurs résultats pour dépister l'ischémie cérébrale pendant le clampage carotidien. L'électroencéphalographie devrait être utilisée avec un nombre élevé de canaux.

Carotid endarterectomy reduces the long-term stroke/death rate of symptomatic patients with a moderate/severe carotid artery stenosis. ${ }^{1}$ Compared with carotid artery stenting, carotid endarterectomy has a lower perioperative (030 days) stroke rate and therefore remains the preferred intervention for symptomatic patients with a moderate/ severe carotid artery stenosis. ${ }^{1,2}$ This surgery can be performed under regional anesthesia, which allows clinical monitoring of the cerebral functions during the carotid artery cross-clamping. ${ }^{3}$ Compared with general anesthesia, regional anesthesia reduces the need for shunt insertion during carotid artery cross-clamping. ${ }^{4,5}$ A liberal use of shunting may increase the long-term incidence of restenosis $;{ }^{6}$ however, not all patients/anesthesiologists/surgeons will agree to proceed under regional anesthesia. It is therefore important to know which monitors are suitable to use when determining which patients require a shunt during carotid artery cross-clamping when surgery is performed under general anesthesia. The aim of the present meta-analysis is to compare the ability of different types of brain monitoring systems $v s$ clinical monitoring of the brain function to detect cerebral ischemia during a carotid artery cross-clamping under regional anesthesia. More specifically, the null hypothesis is that the differences in sensitivity and specificity between the clinical neurological evaluation and stump pressure, transcranial Doppler (TCD), cerebral saturation, electroencephalography (EEG), or evoked potentials will not exceed 1\% (within 95\% credible intervals).

\section{Methods}

The authors developed and approved a protocol before starting this study. In May 2012, a search was conducted (J.G.) in PubMed (from January 1950), Cochrane Central Register of Controlled Trials (April 2012), Cochrane Database of Systematic Reviews (2005 to April 2012), EMBASE (1988 to 2012 Week 18), and Ovid MEDLINE ${ }^{\circledR}$ (1945 to May Week 1 2012) for prospective trials of 20 patients or more where a cerebral monitor was compared with clinical brain monitoring during a carotid endarterectomy performed under regional anesthesia. Reference lists of all retained studies were also checked. Using the Cochrane Collaboration's tool (Table 1) as "yes", "no", or "unclear", the studies were evaluated on the information contained in the reports without any assumption. ${ }^{7}$ Possible duplicate publication was ruled out by checking locations and dates of data collection. Data (true positive, true negative, false positive, and false negative) were extracted independently by the two investigators, and conflicts were resolved by agreement. The authors kept only their best results (lowest sum of false negative + false positive) when the same device was tested with more than one criterion on the same study population. A positive test under regional anesthesia could be defined as: an altered conscious state (unable to answer questions or perform a simple mental task, e.g., counting backward from 100), slurred speech, confusion, severe agitation, aphasia, loss of consciousness, seizure, or motor weakness on the side contralateral to the surgery (e.g., leg and foot paralysis, unable to squeeze a squeaky toy or a bag filled with air or saline and connected to a transducer). Two analyses were performed, one where studies with a zero cell were dropped and a second (to the reviewer's request) where 0.5 was added to all cells of studies with zero cells only.

Data were analyzed for risk of bias assessment with RevMan 5 Version 5.0 (The Nordic Cochrane Centre, Copenhagen) and evaluated for sensitivity, specificity, heterogeneity, positive $(\mathrm{LR}+)$ and negative $(\mathrm{LR}-)$ likelihood ratios, and receiving operator curves with MetaDiSc $^{\circledR}$ Version 1.4 (Madrid, Spain) (http://www.hrc.es/ investigacion/metadisc.html). We assessed heterogeneity with the I-squared statistic, and random effects models were used for all pooled estimates (sensitivity, specificity, 
Table 1 The Cochrane Collaboration's tool for assessing the quality of diagnostic studies

1) Representative spectrum? Did the spectrum of patients represent those who will receive the test in practice?

2) Acceptable reference standard? Is the reference standard likely to classify the target condition correctly?

3) Acceptable delay between tests?

4) Partial verification avoided? Did the whole sample or a random selection of the sample receive verification using a reference standard of diagnosis?

5) Differential verification avoided? Did patients receive the same reference standard regardless of the index test result?

6) Incorporation avoided? Was the reference standard independent of the index test (i.e., the index test did not form part of the reference standard)?

7) Reference standard results blinded? Were the index test results interpreted without knowledge of the results of the reference standard?

8) Index test results blinded? Were the reference standard results interpreted without knowledge of the results of the index test?

9) Relevant clinical information? Were the same clinical data available when test results were interpreted as would be available when the test is used in practice?

10) Uninterpretable results reported? Were uninterpretable/ intermediate test results reported?

11) Withdrawals explained?

diagnostic odds ratio, and likelihood ratios). The JMP ${ }^{\circledR}$ software (SAS Institute Inc., Cary, NC, USA) was used to construct plots of posterior $v s$ prior probabilities $(0.001$, $0.1,0.14,0.2,0.3,0.4,0.5,0.6,0.7,0.9$, and 0.99) from pooled LR+ and LR-. Results were then transferred to Prism (GraphPad Software Inc.; www.graphpad.com) to create Fig. 5. Classical fail-safe numbers to assess publication bias were calculated with Comprehensive Meta Analysis Version 2.2.044 (www.Meta-Analysis.com).

\section{Results}

A flow chart for the selection of the studies is shown in Fig. 1, and an evaluation of the quality of the studies is shown in Fig. 2. A list of all articles retrieved is available as Electronic Supplementary Material (Appendix). Details of the study are presented in Table 2. Data were extracted for 4,664 measurements taken from 29 studies (transcranial Doppler $=739$; cerebral saturation $=320$; stump pressure $=2,549 ; \quad$ EEG $=742 ; \quad$ evoked potentials $=187$; jugular venous saturation $=79$; and jugular venous lactate $=48)\left(\right.$ Fig. 3). ${ }^{8-36}$ Agreement before discussion was achieved in 92 of 156 extractions (true positive, false positive, true negative, and false negative for each test) for a kappa statistic of 0.59. All discrepancies were resolved after discussion. Sensitivity, specificity, area under the curve, diagnostic odds ratio (DOR), LR + and $\mathrm{LR}-$ are given in Table 3. Inclusion of studies with zero cells improved most DORs (except EEG) but did not change the fact that the two best monitors were TCD and EEG (Table 4). The classical fail-safe numbers (i.e., number of negative studies required to render the DOR non-statistically significant) were 99 for TCD, 153 for EEG, and 15 for cerebral saturation. A moderate amount (Isquare $=56.2 \%$ ) of heterogeneity was found on the DOR for EEG. A meta-regression revealed that the DOR improved significantly with the number of channels used $(P \quad$ value $=0.03) \quad$ (Fig. 4). Posterior probabilities for sequential testing with stump pressure $25 \mathrm{mmHg}$ and each of TCD, cerebral saturation, EEG, or evoked potentials are given in Fig. 5. Assuming a $14 \%$ incidence of shunt requirement, ${ }^{5}$ the chances of requiring a shunt when two tests are positive would be $90.0 \%$ for stump pressure $25 \mathrm{mmHg}$ and TCD; $77.5 \%$ for stump pressure $25 \mathrm{mmHg}$ and cerebral saturation; 93\% for stump pressure $25 \mathrm{mmHg}$ and EEG; and $75.0 \%$ for stump pressure $25 \mathrm{mmHg}$ and evoked potentials. The chances of requiring a shunt when two tests are negative would be $1.4 \%$ for stump pressure $25 \mathrm{mmHg}$ and TCD; $2.5 \%$ for stump pressure $25 \mathrm{mmHg}$ and cerebral saturation; $2.4 \%$ for stump pressure $25 \mathrm{mmHg}$ and EEG; and $1.5 \%$ for stump pressure $25 \mathrm{mmHg}$ and evoked potentials.

\section{Discussion}

Our results show that a combination of stump pressure and either TCD or EEG appears to deliver the best results for detecting brain ischemia during carotid artery crossclamping. To achieve best results, EEG should be used with a high number of channels. Ambiguity of blinding was an obvious flaw for most of the studies included. The effect of absence of blinding on the results is difficult to evaluate precisely, but it is certainly possible that the capabilities of the various monitors studied to detect cerebral ischemia were overestimated. Bias in systematic reviews of diagnostic tests would increase the sensitivity (no systematic effect on specificity). ${ }^{7,37}$

Studies with empty cells are problematic. The addition of a fraction to those cells or to all cells has been proposed as a solution to circumvent this issue, but this technique is 


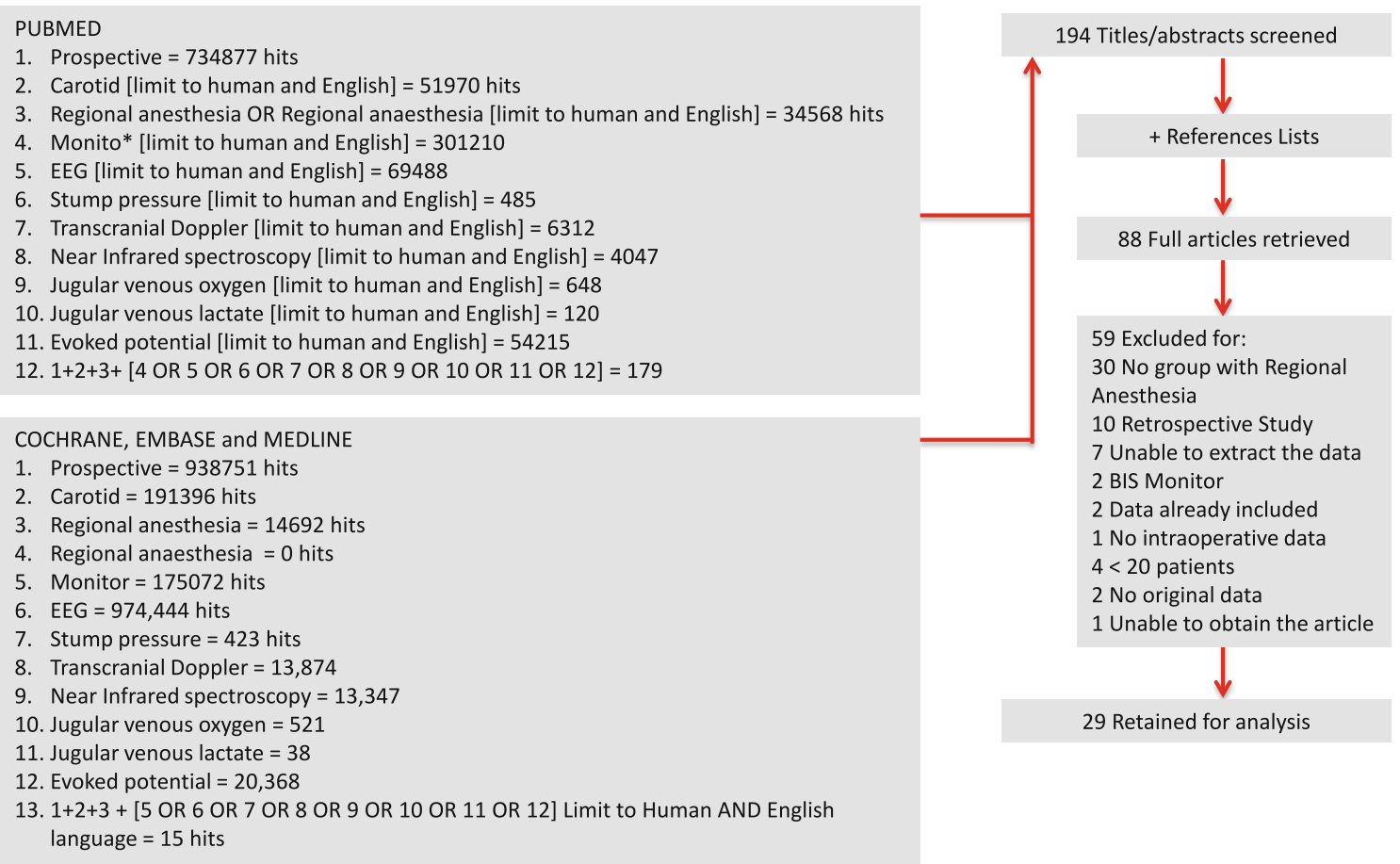

Fig. 1 Flow chart for the selection of the studies. EEG = electroencephalography

controversial as it may increase heterogeneity (Table 4) and introduce bias in the results. In developing the protocol, we therefore specified that all studies with an empty cell would be dropped in the final analysis; however, by doing so, we may have underestimated the accuracy of the monitors. The exact cut-off point used to determine the

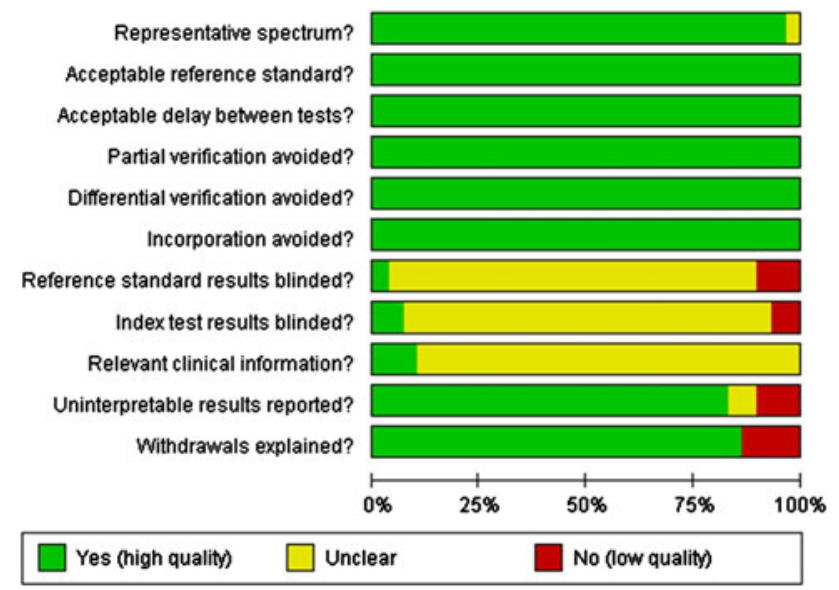

Fig. 2 Evaluation of the quality of the studies included in the analysis according to the Cochrane Collaboration's tool for systematic reviews of diagnostic tests. Green $=\%$ of the studies for which this specific item was judged to be adequate; red $=\%$ of the studies for which this specific item was judged to be inadequate; yellow $=\%$ of the studies for which there was not enough information in the article to judge this item shunt requirement varied from one study to another. Instead of evaluating a cut-off point determined a priori, the investigators often gave us a cut-off point that best fit their data. Changing the cut-off point will affect the monitor's performance. For example, a stump pressure of $25 \mathrm{mmHg}$ may be more specific but less sensitive than a stump pressure of $40 \mathrm{mmHg}$. Based on our protocol, we chose to extract data from each study that gave the best results (lowest sum of false positive + false negative) so as to keep the best accuracy of each monitor. This may have overestimated the performance of the monitors evaluated. The definition used to define the "gold standard" (Table 2) varies from one study to another. This may have affected the performance of the "gold standard"; however, regardless of the sign or symptom, we consider any new neurological sign/ symptom (global or focal) that appears during carotid artery cross-clamping (provided that the patient is not oversedated) to be interpreted as suboptimal brain oxygenation until proven otherwise. Consequently, our a priori definition was extensive, and no study was excluded for this specific reason. Finally, the search was limited to the English language. The effect of language restriction has been evaluated and, for conventional intervention (as opposed to complementary and alternative medicine), a search limited to the English language is unlikely to introduce a significant bias into the conclusions. $^{38}$

Taken separately, none of the monitors can detect cerebral ischemia to the same extent as regional anesthesia. 


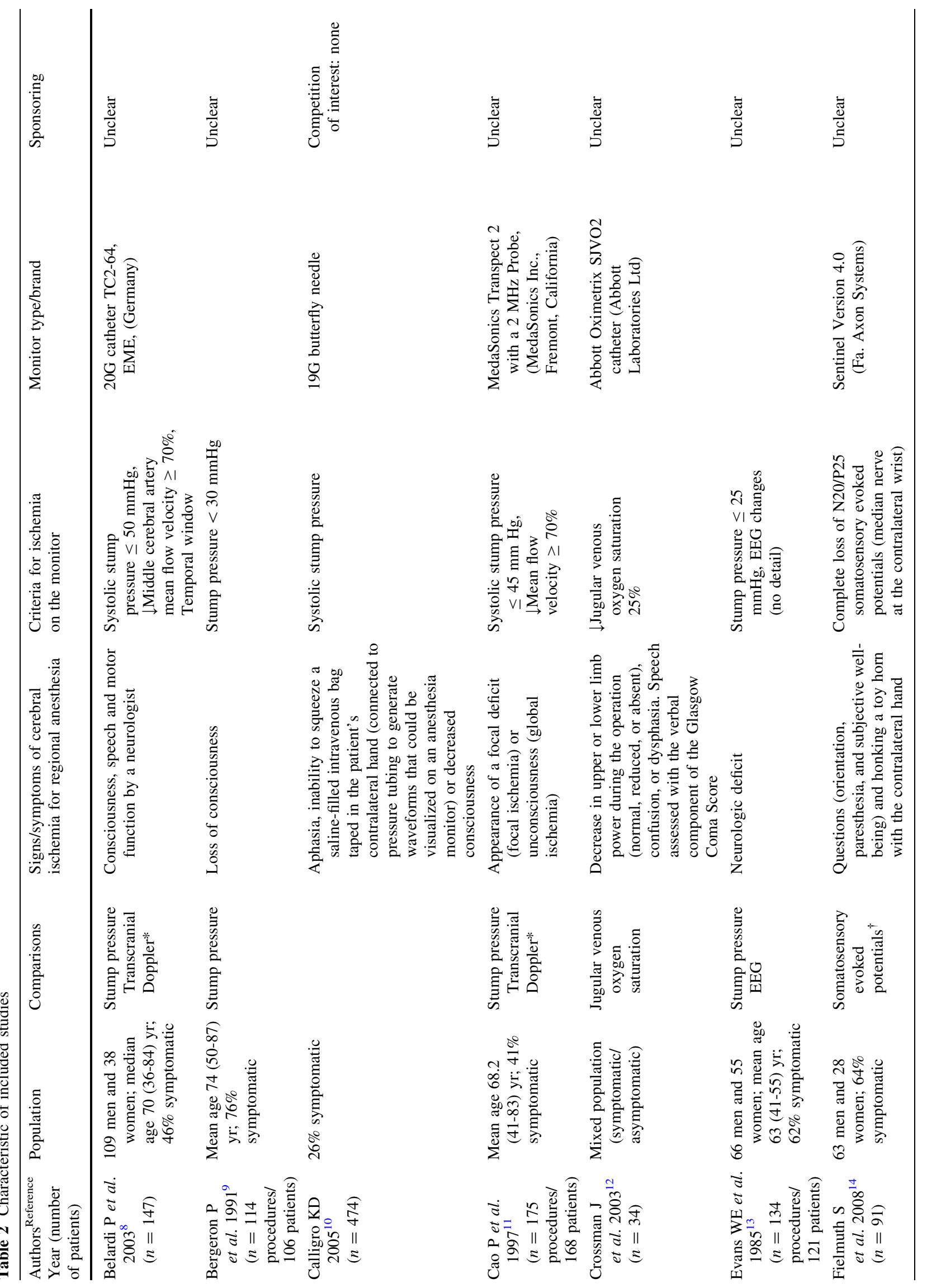




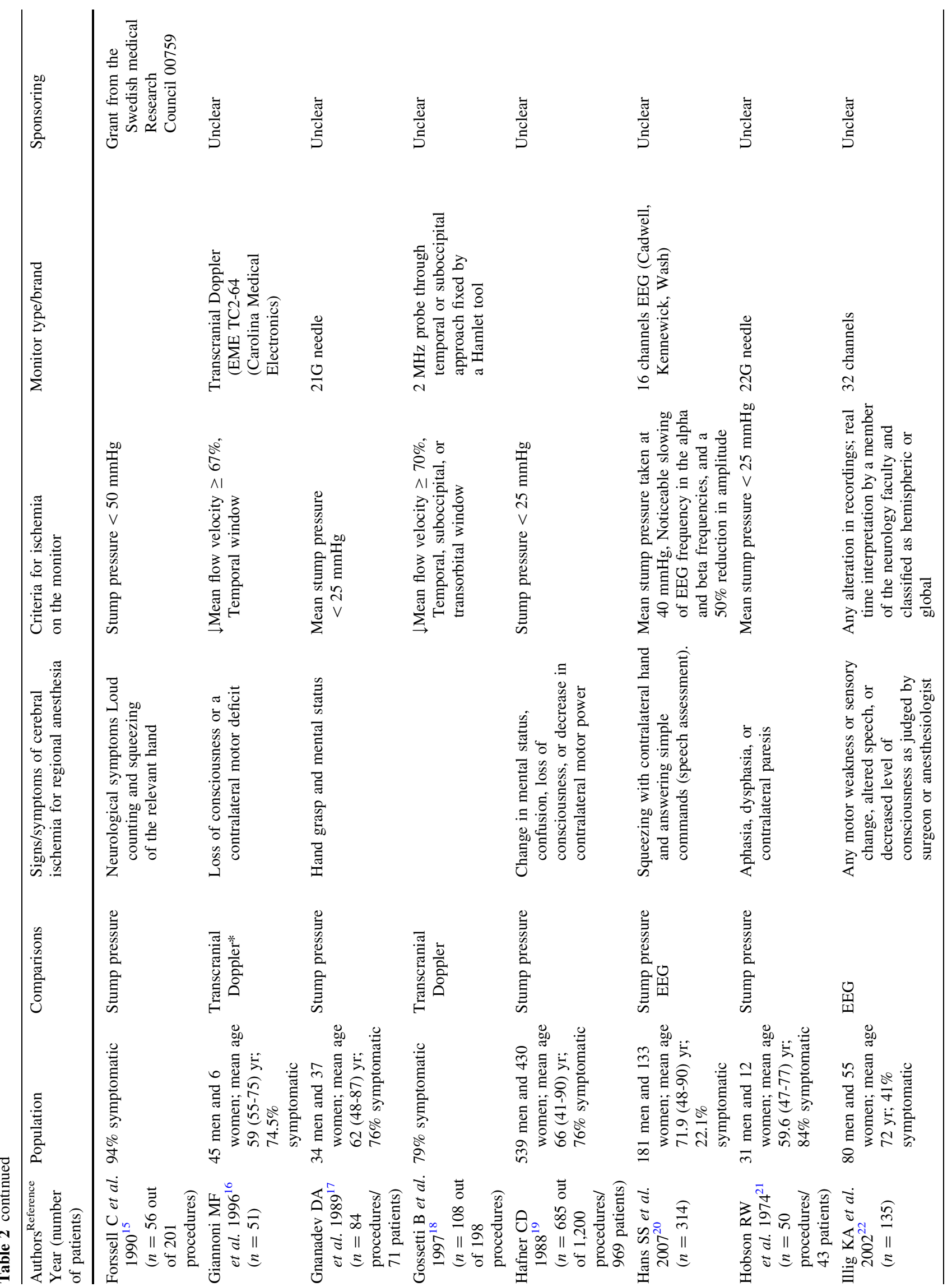




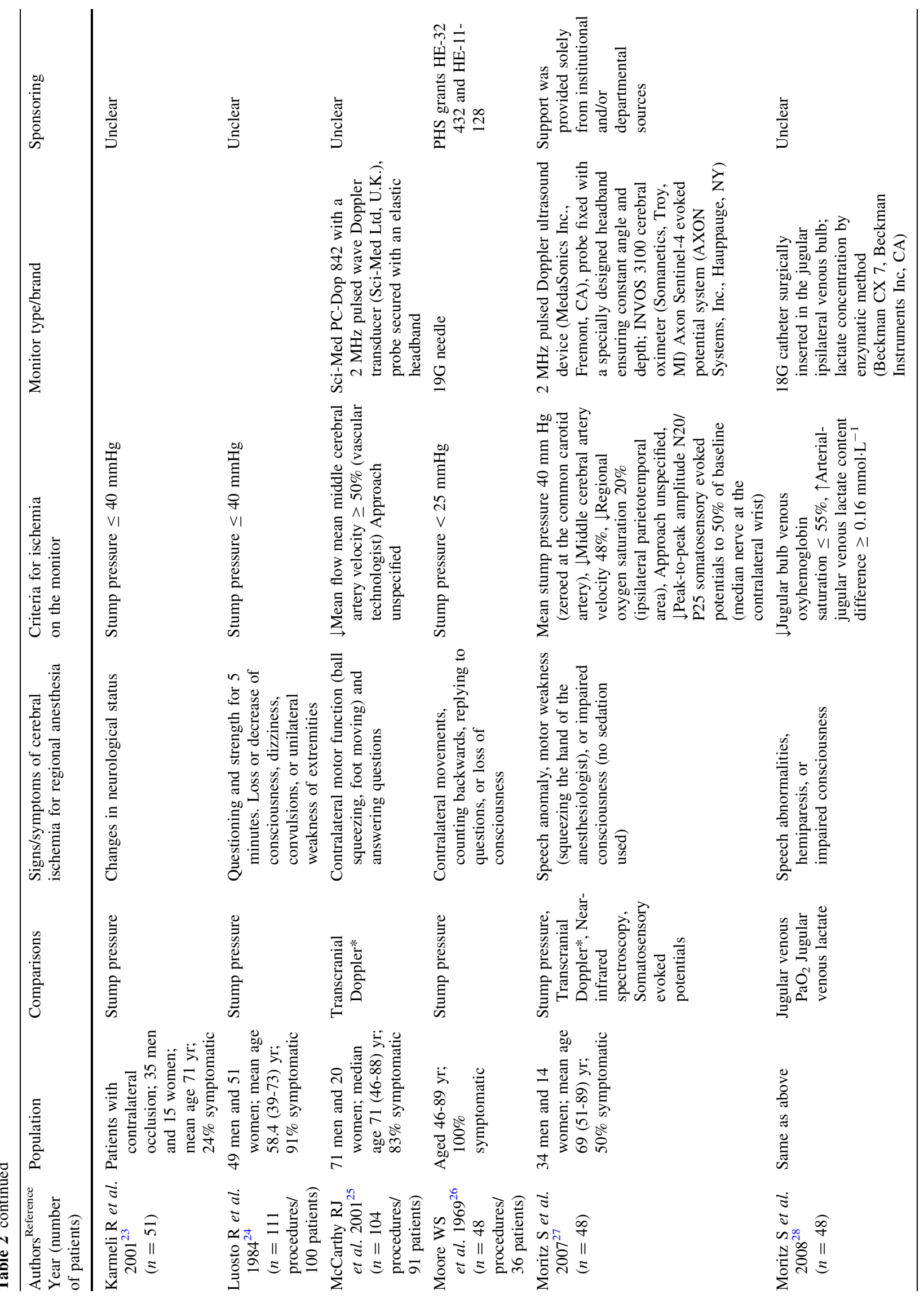




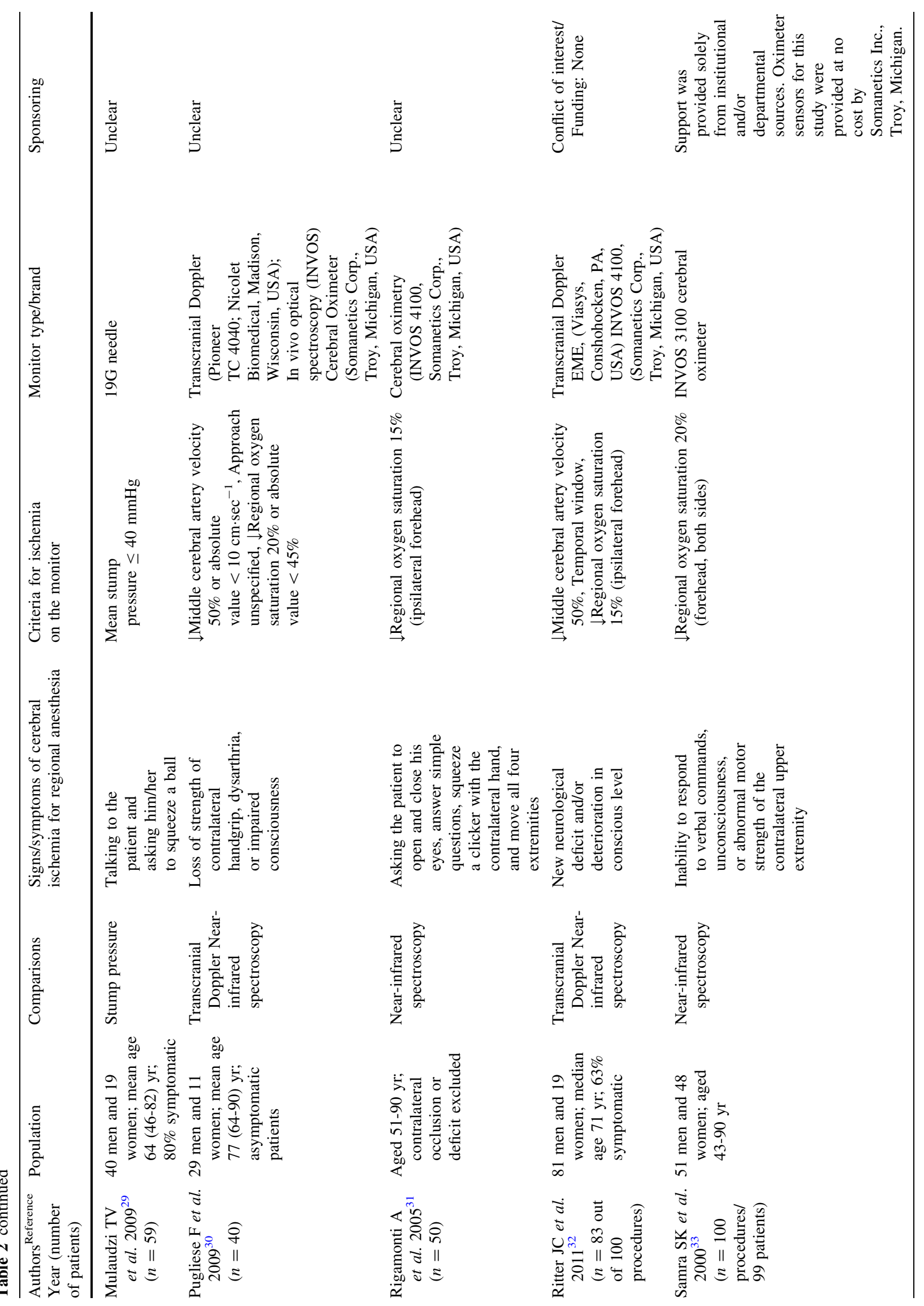




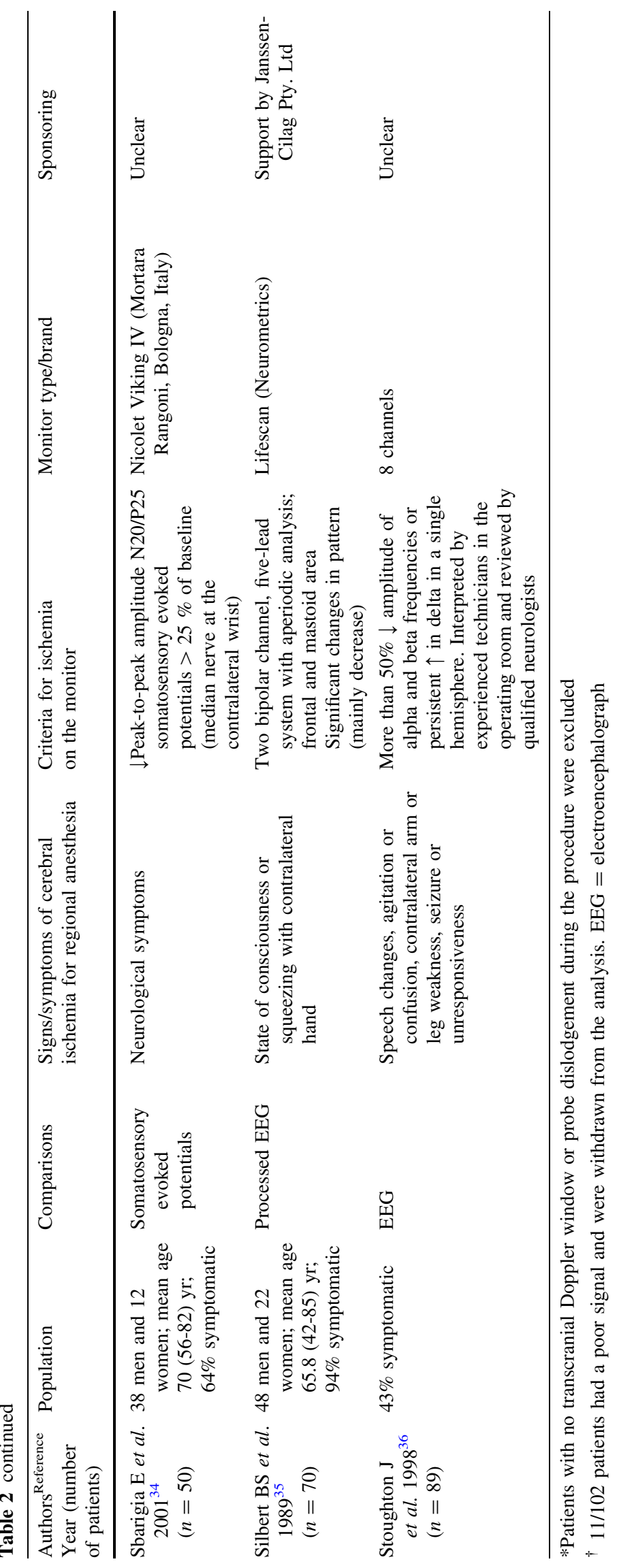


Diagnostic odds ratio for TCD, EEG, CS and EP

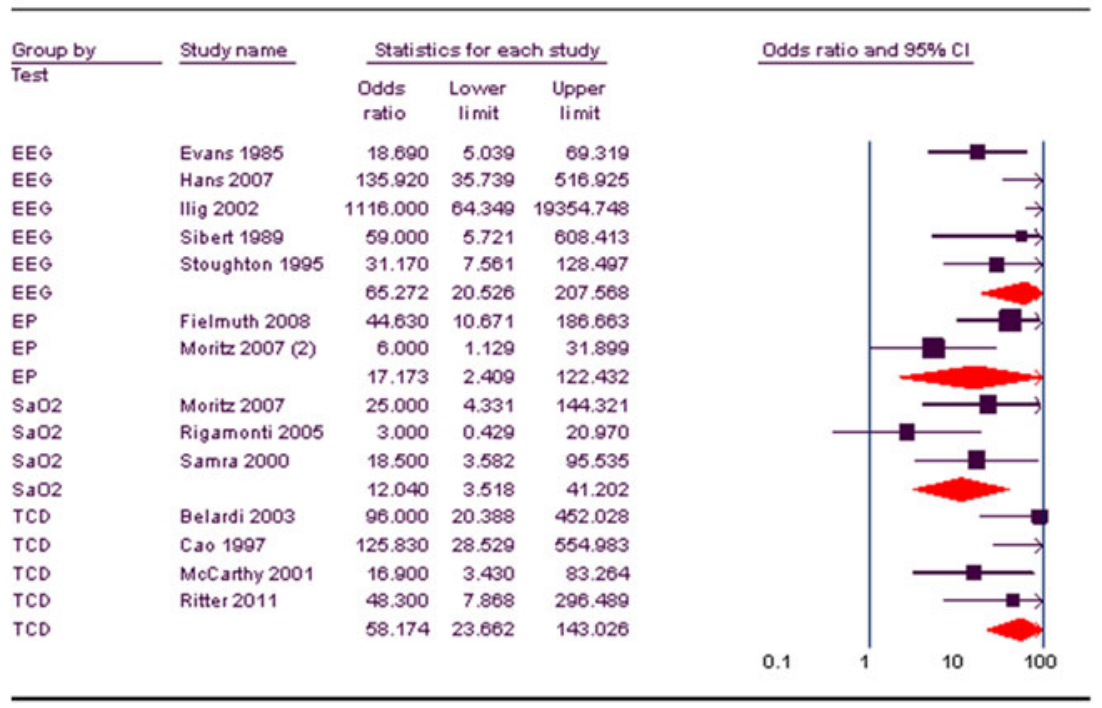

Fig. 3 Forest plots of diagnostic odds ratios for transcranial Doppler (TCD), electroencephalography (EEG), cerebral saturation (CS), and evoked potentials (EP). The diagnostic odds ratio (ratio of the odds of positivity in disease relative to the odds of positivity in the nondiseased) expresses the strength of the association between test result and disease. Inconsistency (as measured by the I-square value) is the percentage of variation in effect from one study to another that cannot be explained by chance alone: $25 \%$ is low, $50 \%$ is moderate, and $75 \%$ is high. I-square was $24.9 \%$ for TCD, $56.8 \%$ for EEG, $30.8 \%$ for CS, and $69.1 \%$ for EP

Table 3 Results for all monitors

\begin{tabular}{|c|c|c|c|c|c|c|c|}
\hline $\begin{array}{l}\text { Monitor (number of } \\
\text { studies with/without } \\
\text { empty cell for AUC) }\end{array}$ & $\begin{array}{l}\text { Sensitivity } \\
(95 \% \mathrm{CI}) \\
\text { [I-square] }\end{array}$ & $\begin{array}{l}\text { Specificity } \\
(95 \% \mathrm{CI}) \\
{[\text { I-square] }}\end{array}$ & $\begin{array}{l}\text { AUC } \\
(\mathrm{SE}) \\
{[\mathrm{Q}]}\end{array}$ & $\begin{array}{l}\text { DOR } \\
(95 \% \mathrm{CI}) \\
\text { [I-square] }\end{array}$ & $\begin{array}{l}\mathrm{LR}+ \\
(95 \% \mathrm{CI}) \\
{[\mathrm{I}-\text { square] }}\end{array}$ & $\begin{array}{l}\mathrm{LR}- \\
(95 \% \mathrm{CI}) \\
{[\mathrm{I}-\text { square] }}\end{array}$ & $\begin{array}{l}\text { Cut-off } \\
\text { points } \\
\text { (range) }\end{array}$ \\
\hline $\operatorname{TCD}(n=8 / 4)$ & $\begin{array}{l}0.81(0.69 \\
\text { to } 0.91) \\
{[0 \%]}\end{array}$ & $\begin{array}{r}0.92(0.89 \\
\text { to } 0.94) \\
{[88.9 \%]}\end{array}$ & $\begin{array}{l}0.896 \\
\quad(0.044) \\
{[0.827]}\end{array}$ & $\begin{array}{l}58.1(23.0 \\
\quad \text { to } 146.3) \\
\quad[24.9 \%]\end{array}$ & $\begin{array}{c}11.22(3.93 \\
\text { to } 32.03) \\
{[87.5 \%]}\end{array}$ & $\begin{array}{l}0.20(0.12 \\
\quad \text { to } 0.36) \\
{[0 \%]}\end{array}$ & $\downarrow 48-70 \%$ \\
\hline $\begin{array}{l}\text { Cerebral Saturation } \\
\qquad(n=5 / 3)\end{array}$ & $\begin{array}{r}0.74(0.54 \\
\text { to } 0.89) \\
{[40.3 \%]}\end{array}$ & $\begin{array}{l}0.82(0.76 \\
\quad \text { to } 0.88) \\
{[0 \%]}\end{array}$ & $\begin{array}{l}0.897 \\
\quad(0.043) \\
{[0.828]}\end{array}$ & $\begin{array}{l}12.1(3.52 \\
\quad \text { to } 41.24) \\
{[30.8 \%]}\end{array}$ & $\begin{array}{l}4.28(2.82 \\
\quad \text { to } 6.50) \\
{[0 \%]}\end{array}$ & $\begin{array}{r}0.36(0.13 \\
\text { to } 1.02) \\
{[64.3 \%]}\end{array}$ & $\downarrow 15-20 \%$ \\
\hline $\begin{array}{l}\text { Stump pressure } \\
\quad(n=15 / 9)\end{array}$ & $\begin{array}{r}0.75(0.69 \\
\text { to } 0.81) \\
{[88.2 \%]}\end{array}$ & $\begin{array}{r}0.88(0.86 \\
\text { to } 0.89) \\
{[89.6 \%]}\end{array}$ & $\begin{array}{l}0.930 \\
\quad(0.018) \\
{[0.865]}\end{array}$ & $\begin{array}{l}27.84 \\
\quad(13.38 \text { to } \\
57.94) \\
{[59.9 \%]}\end{array}$ & $\begin{array}{r}6.59(4.64 \\
\text { to } 9.37\} \\
{[76.3 \%]}\end{array}$ & $\begin{array}{r}0.28(0.13 \\
\text { to } 0.59) \\
{[93.1 \%]}\end{array}$ & $25-50 \mathrm{mmHg}$ \\
\hline Stump $25 \mathrm{mmHg}$ & $\begin{array}{r}0.67(0.57 \\
\text { to } 0.76) \\
{[94.8 \%]}\end{array}$ & $\begin{array}{r}0.85(0.83 \\
\text { to } 0.88) \\
{[94.2 \%]}\end{array}$ & $\begin{array}{l}0.941 \\
\quad(0.022) \\
{[0.879]}\end{array}$ & $\begin{array}{c}19.37(4.54 \\
\quad \text { to } 82.62) \\
{[73.2 \%]}\end{array}$ & $\begin{array}{l}4.95(4.22 \\
\quad \text { to } 5.81) \\
{[0 \%]}\end{array}$ & $\begin{array}{r}0.44(0.17 \\
\text { to } 1.13) \\
{[95.2 \%]}\end{array}$ & $25 \mathrm{mmHg}$ \\
\hline Stump $40 \mathrm{mmHg}$ & $\begin{array}{l}0.82(0.73 \\
\quad \text { to } 0.89) \\
{[0 \%]}\end{array}$ & $\begin{array}{r}0.90(0.88 \\
\text { to } 0.92) \\
{[79.9 \%]}\end{array}$ & $\begin{array}{l}0.897 \\
\quad(0.041) \\
{[0.828]}\end{array}$ & $\begin{array}{l}31.33 \\
\quad(10.81 \text { to } \\
90.81) \\
{[83.5 \%]}\end{array}$ & $\begin{array}{l}6.38(3.34 \\
\quad \text { to } 12.18) \\
{[85.4 \%]}\end{array}$ & $\begin{array}{l}0.23(0.15 \\
\quad \text { to } 0.35) \\
{[0 \%]}\end{array}$ & $40 \mathrm{mmHg}$ \\
\hline EEG $(n=5 / 5)$ & $\begin{array}{r}0.70(0.58 \\
\text { to } 0.80) \\
{[13.1 \%]}\end{array}$ & $\begin{array}{r}0.96(0.94 \\
\text { to } 0.97) \\
{[85.8 \%]}\end{array}$ & $\begin{array}{l}0.864 \\
\quad(0.060) \\
{[0.795]}\end{array}$ & $\begin{array}{l}65.27 \\
\quad(20.51 \text { to } \\
207.71) \\
{[56.8 \%]}\end{array}$ & $\begin{array}{c}16.70(6.59 \\
\quad \text { to } 42.37) \\
{[78.0 \%]}\end{array}$ & $\begin{array}{l}0.35(0.25 \\
\quad \text { to } 0.49) \\
{[0 \%]}\end{array}$ & \\
\hline $\begin{array}{l}\text { Evoked } \\
\quad \text { potentials } \\
\quad(n=3 / 2)\end{array}$ & $\begin{array}{l}0.84(0.66 \\
\text { to } 0.95) \\
{[0 \%]}\end{array}$ & $\begin{array}{r}0.78(0.69 \\
\text { to } 0.86) \\
{[92.4 \%]}\end{array}$ & NA & $\begin{array}{c}17.17(2.38 \\
\text { to } \\
123.85) \\
{[69.1 \%]}\end{array}$ & $\begin{array}{l}3.72(0.89 \\
\quad \text { to } 15.52) \\
{[91.6 \%]}\end{array}$ & $\begin{array}{l}0.22(0.10 \\
\quad \text { to } 0.49) \\
{[0 \%]}\end{array}$ & $\begin{array}{c}\mathrm{N} 20 / \mathrm{P} 250-50 \% \\
\text { of baseline }\end{array}$ \\
\hline $\begin{array}{l}\text { Jugular venous } \\
\text { saturation } \\
(n=2 / 1)\end{array}$ & $\begin{array}{r}0.75(0.43 \\
\text { to } 0.95)\end{array}$ & $\begin{array}{r}0.83(0.67 \\
\text { to } 0.94)\end{array}$ & NA & NA & NA & NA & $\leq 55 \%$ \\
\hline
\end{tabular}


Table 3 continued

\begin{tabular}{|c|c|c|c|c|c|c|c|}
\hline $\begin{array}{l}\text { Monitor (number of } \\
\text { studies with/without } \\
\text { empty cell for AUC) }\end{array}$ & $\begin{array}{l}\text { Sensitivity } \\
(95 \% \mathrm{CI}) \\
\text { [I-square] }\end{array}$ & $\begin{array}{l}\text { Specificity } \\
(95 \% \mathrm{CI}) \\
\text { [I-square] }\end{array}$ & $\begin{array}{l}\text { AUC } \\
\text { (SE) } \\
{[Q]}\end{array}$ & $\begin{array}{l}\text { DOR } \\
\text { (95\% CI) } \\
\text { [I-square] }\end{array}$ & $\begin{array}{l}\text { LR+ } \\
\text { (95\% CI) } \\
\text { [I-square] }\end{array}$ & $\begin{array}{l}\text { LR- } \\
(95 \% \text { CI) } \\
\text { [I-square] }\end{array}$ & $\begin{array}{l}\text { Cut-off } \\
\text { points } \\
\text { (range) }\end{array}$ \\
\hline $\begin{array}{l}\text { Jugular venous } \\
\text { lactate } \\
(n=1)\end{array}$ & $\begin{array}{l}0.67 \\
(0.35 \\
\text { to } 0.90)\end{array}$ & $\begin{array}{l}0.86 \\
(0.71 \\
\text { to } 0.95)\end{array}$ & NA & NA & NA & NA & $\begin{array}{l}\geq 0.16 \\
\mathrm{mmol} \cdot \mathrm{L}^{-1}\end{array}$ \\
\hline
\end{tabular}

Random effects models. AUC = area under the curve; 95\% CI = 95\% confidence interval; DOR = diagnostic odds ratio; LR $+=$ positive likelihood ratio; $\mathrm{LR}-=$ negative likelihood ratio; $\mathrm{TCD}=$ transcranial Doppler; $\mathrm{EEG}=$ electroencephalography; $\mathrm{NA}=$ not available due to insufficient number of studies

Fig. 4 A meta-regression revealed that the diagnostic odds ratio for EEG increases with the number of channels used $(P=0.03)$

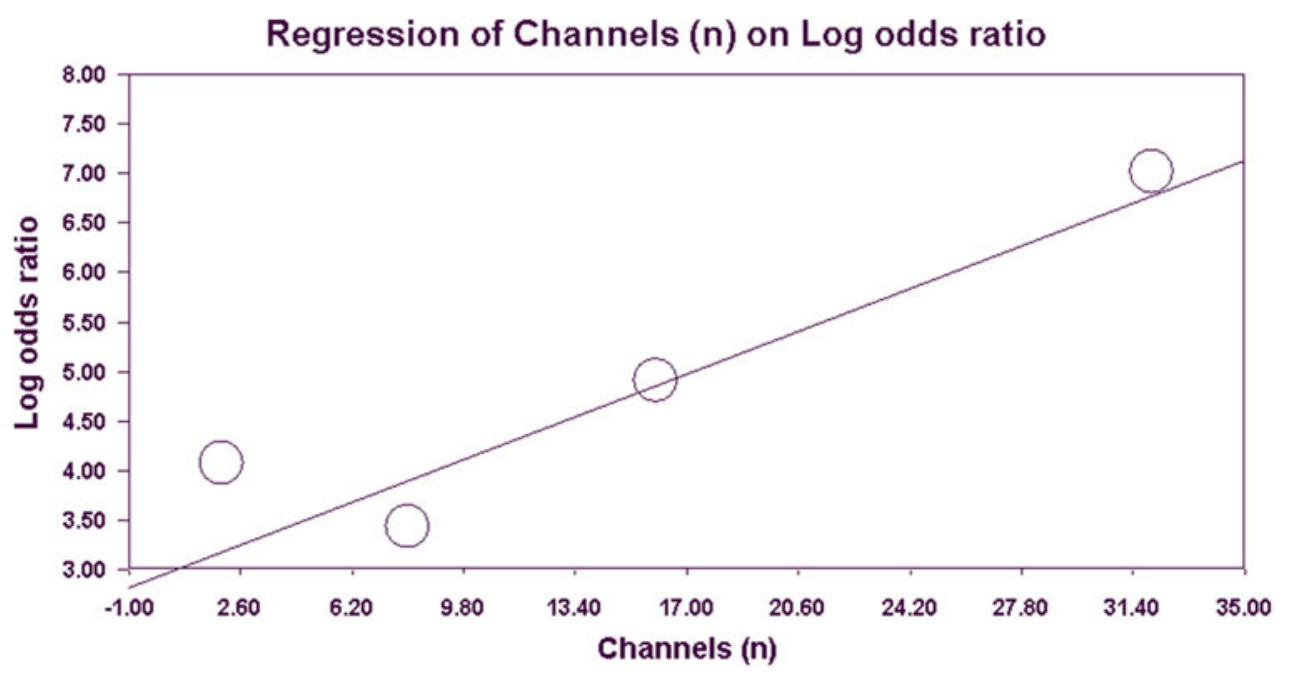

Association of stump pressure with TCD or EEG seems to be the best combination if, fortuitously, results of both tests are on the same side (positive $v s$ negative) (Fig. 5). The inherent limits/costs of tests may also affect choice. For example, approximately $10 \%$ of patients lack a temporal window that would allow TCD monitoring. Alternate approaches have been proposed to circumvent this problem. ${ }^{17}$ The close proximity of the monitor to the surgical site has also been a problem, with some investigators reporting probe displacement during the surgery. Simplified EEG (BIS monitor) proved unfit for this task, and because the interpretation of a conventional EEG requires specialized knowledge, the availability of the technician/ neurologist limits the use of an EEG for this purpose. When EEG is chosen, our meta-analysis suggests that a high number of channels should give the best accuracy (Fig. 4). Some drugs used to induce and maintain general anesthesia will affect EEG and evoked potentials, making the ability of these two monitors to detect brain ischemia in patients under general anesthesia uncertain.

The ultimate decision whether or not to insert a shunt will also involve consideration of other variables, such as specific difficulties of shunt insertion (e.g., long plaques extending distally into the cranium, small vessels etc.), stenosis/occlusion of the collateral vessels, capability of the patient to support an increase in systemic arterial blood pressure (failing heart), or timing of ischemia (a brief period of ischemia close to restoration of blood flow may be less risky than a shunt insertion).

Finally, it is important to bear in mind that accuracy of tests constitutes a surrogate marker for important outcomes. In our study, the evaluation was based on cerebral ischemia as attested by a variety of clinical signs and symptoms, while the obvious important outcome would be a change in the stroke/death rate (critical to a decision or 7-9 on a 9-point rating scale). ${ }^{39}$ Assuming that strokes could be prevented by a better diagnosis of cerebral ischemia during artery cross-clamping implies not only that no (or a low rate of) bad consequences would be expected from the shunt placement itself but also that ischemic strokes constitute a sufficiently important fraction of all strokes to make a clinically relevant difference or that an early diagnosis of embolic strokes would change the overall prognosis. The Grading of Recommendations Assessment, Development and Evaluation (GRADE) Working Group considers that "accuracy studies typically provide low-quality evidence for making recommendations owing to indirectness of the outcomes, similar to 


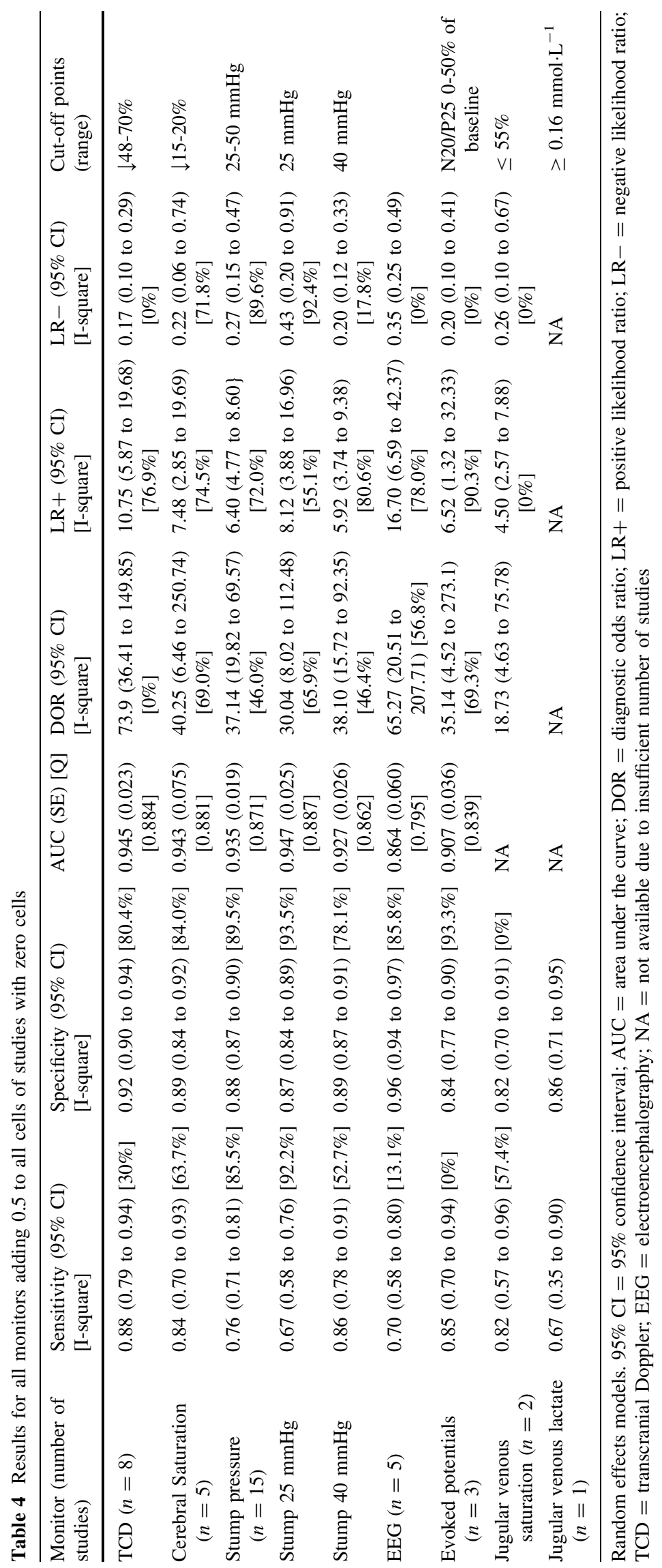




\section{Posterior Probabilities for Sequential Testing}

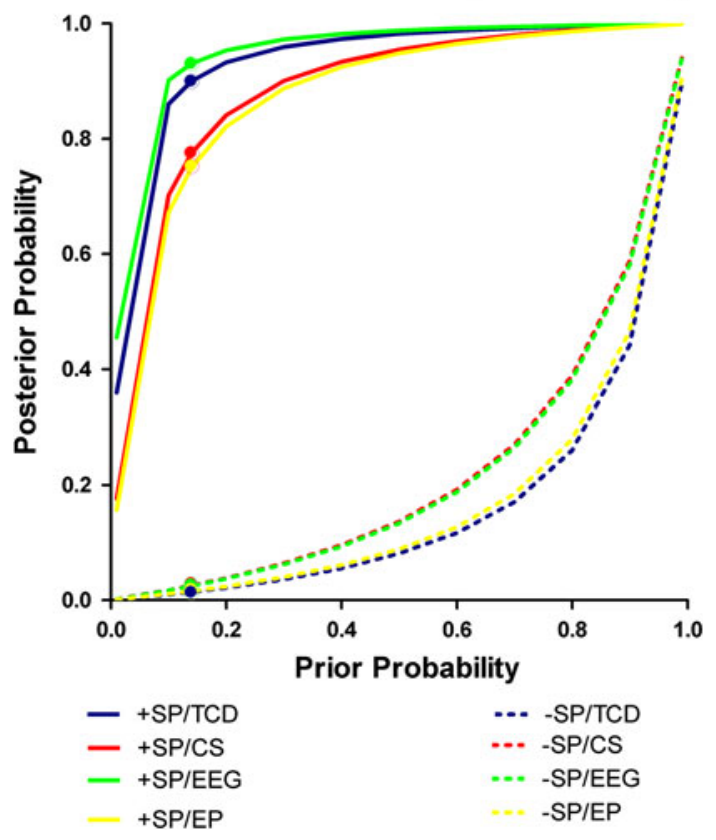

Fig. 5 Graph of the posterior probabilities $v s$ the prior probabilities for sequential testing with stump pressure with a cut-off point at $25 \mathrm{mmHg}$, followed by transcranial Doppler (TCD), cerebral saturation (CS), electroencephalography (EEG), or evoked potentials (EP) for a positive or negative (dashed lines) test. Points are the results for a prior probability of $14 \%$

surrogate outcomes for treatments." 39 The second important outcome here (which justified undertaking the present study) was that a more accurate diagnosis of cerebral ischemia could decrease unnecessary shunt placements in patients operated under general anesthesia, a practice which itself may lead to restenosis (based on a large retrospective study) (important to a decision or 4-6 on a 9-point rating scale). Nevertheless, a low (TCD) or moderate (EEG) amount of heterogeneity on the DOR coupled with uncertainty around the results (wide confidence intervals) reduces the quality of the evidence. Therefore, a prospective randomized study evaluating the efficacy of our proposed strategy to reduce the rate of long-term restenosis or costs associated with shunt placements (without increasing the stroke/death rate) would be required before making any firm recommendation.

In conclusion, no monitor can reproduce the detection of brain ischemia achievable with regional anesthesia. A combination of stump pressure and either TCD or EEG appears to give the best results. For EEG, a high number of channels should be used. A randomized clinical trial evaluating this strategy is required before any firm conclusion can be drawn.

Acknowledgements We sincerely thank Maisonneuve-Rosemont Hospital and University of Montreal for providing some of the references used for the preparation of this study and for access to electronic databases.

Conflicts of interest None declared.

\section{References}

1. Guay J, Ochroch EA. Carotid endarterectomy plus medical therapy or medical therapy alone for carotid artery stenosis in symptomatic or asymptomatic patients: a meta-analysis. J Cardiothorac Vasc Anesth 2012; 26: 835-44.

2. Guay J. Endovascular stenting or carotid endarterectomy for treatment of carotid stenosis: a meta-analysis. J Cardiothorac Vasc Anesth 2011; 25: 1024-9.

3. Guay J. Regional anesthesia for carotid surgery. Curr Opin Anaesthesiol 2008; 21: 638-44.

4. Guay J. The GALA trial: answers it gives, answers it does not. Lancet 2008; 372: 2092-3.

5. GALA Trial Collaborative Group, Lewis SC, Warlow CP, Bodenham AR, et al. General anaesthesia versus local anaesthesia for carotid surgery (GALA): a multicentre, randomised controlled trial. Lancet 2008; 372: 2132-42.

6. Hudorovic N, Lovricevic I, Hajnic H, Ahel Z. Postoperative internal carotid artery restenosis after local anesthesia: presence of risk factors versus intraoperative shunt. Interact Cardiovasc Thorac Surg 2010; 11: 182-4.

7. Reitsma JB, Rutjes AW, Whiting P, Vlassov VV, Leeflang $M M$, Deeks JJ. Chapter 9: Assessing methodological quality. In: Deeks JJ, Bossuyt PM, Gatsonis C (Eds). Cochrane Handbook for Systematic Reviews of Diagnostic Test Accuracy Version 1.0.0. The Cochrane Collaboration, 2009. Available from URL: http://srdta.cochrane.org/ (accessed September 9, 2012).

8. Belardi P, Lucertini G, Ermirio D. Stump pressure and transcranial Doppler for predicting shunting in carotid endarterectomy. Eur J Vasc Endovasc Surg 2003; 25: 164-7.

9. Bergeron P, Benichou H, Rudondy P, Jausseran JM, Ferdani M, Courbier $R$. Stroke prevention during carotid surgery in high risk patients (value of transcranial Doppler and local anesthesia). J Cardiovasc Surg (Torino) 1991; 32: 713-9.

10. Calligaro KD, Dougherty MJ. Correlation of carotid artery stump pressure and neurologic changes during 474 carotid endarterectomies performed in awake patients. J Vasc Surg 2005; 42: 684-9.

11. Cao P, Giordano G, Zannetti S, et al. Transcranial Doppler monitoring during carotid endarterectomy: is it appropriate for selecting patients in need of a shunt? J Vasc Surg 1997; 26: 973-9.

12. Crossman J, Banister K, Bythell V, Bullock R, Chambers I, Mendelow $A D$. Predicting clinical ischaemia during awake carotid endarterectomy: use of the SJVO2 probe as a guide to selective shunting. Physiol Meas 2003; 24: 347-54.

13. Evans WE, Hayes JP, Waltke EA, Vermilion BD. Optimal cerebral monitoring during carotid endarterectomy: neurologic response under local anesthesia. J Vasc Surg 1985; 2: 775-7.

14. Fielmuth $S$, Uhlig $T$. The role of somatosensory evoked potentials in detecting cerebral ischaemia during carotid endarterectomy. Eur J Anaesthesiol 2008; 25: 648-56.

15. Forssell $C$, Takolander $R$, Bergqvist D. Pressure measurements as predictors for peroperative neurologic deficits in carotid surgery. Eur J Vasc Surg 1990; 4: 153-8.

16. Giannoni MF, Sbarigia E, Panico MA, et al. Intraoperative transcranial Doppler sonography monitoring during carotid surgery under locoregional anaesthesia. Eur J Vasc Endovasc Surg 1996; 12: 407-11. 
17. Gnanadev DA, Wang N, Comunale FL, Reile DA. Carotid artery stump pressure: how reliable is it in predicting the need for a shunt? Ann Vasc Surg 1989; 3: 313-7.

18. Gossetti B, Martinelli O, Guerricchio R, Irace L, BenedettiValentini $F$. Transcranial Doppler in 178 patients before, during, and after carotid endarterectomy. J Neuroimaging 1997; 7: 213-6.

19. Hafner $C D$, Evans WE. Carotid endarterectomy with local anesthesia: results and advantages. J Vasc Surg 1988; 7: 232-9.

20. Hans SS, Jareunpoon O. Prospective evaluation of electroencephalography, carotid artery stump pressure, and neurologic changes during 314 consecutive carotid endarterectomies performed in awake patients. J Vasc Surg 2007; 45: 511-5.

21. Hobson RW 2nd, Wright CB, Sublett JW, Fedde CW, Rich NM. Carotid artery back pressure and endarterectomy under regional anesthesia. Arch Surg 1974; 109: 682-7.

22. Illig KA, Sternbach $Y$, Zhang $R$, et al. EEG changes during awake carotid endarterectomy. Ann Vasc Surg 2002; 16: 6-11.

23. Karmeli R, Lubezky N, Halak M, Loberman Z, Weller B, Fajer S. Carotid endarterectomy in awake patients with contralateral carotid artery occlusion. Cardiovasc Surg 2001; 9: 334-8.

24. Luosto $R$, Ketonen $P$, Mattila $S$, Takkunen $O$, Eerola $S$. Local anaesthesia in carotid surgery. A prospective study of 111 endarterectomies in 100 patients. Scand J Thorac Cardiovasc Surg 1984; 18: 133-7.

25. McCarthy RJ, McCabe AE, Walker R, Horrocks $M$. The value of transcranial Doppler in predicting cerebral ischaemia during carotid endarterectomy. Eur J Vasc Endovasc Surg 2001; 21: 408-12.

26. Moore WS, Hall AD. Carotid artery back pressure: a test of cerebral tolerance to temporary carotid occlusion. Arch Surg 1969; 99: 702-10.

27. Moritz S, Kasprzak P, Arlt M, Taeger K, Metz C. Accuracy of cerebral monitoring in detecting cerebral ischemia during carotid endarterectomy: a comparison of transcranial Doppler sonography, near-infrared spectroscopy, stump pressure, and somatosensory evoked potentials. Anesthesiology 2007; 107: 563-9.

28. Moritz S, Kasprzak P, Woertgen $C$, Taeger $K$, Metz $C$. The accuracy of jugular bulb venous monitoring in detecting cerebral ischemia in awake patients undergoing carotid endarterectomy. J Neurosurg Anesthesiol 2008; 20: 8-14.

29. Mulaudzi TV, Biccard BM, Robbs JV, Paruk N, Pillay B, Rajaruthnam $P$. Carotid artery stump pressure and associated neurological changes in predominantly symptomatic carotid artery disease patients undergoing awake carotid endarterectomy. Cardiovasc J Afr 2009; 20: 116-8.

30. Pugliese $F$, Ruberto $F$, Tosi A, et al. Regional cerebral saturation versus transcranial Doppler during carotid endarterectomy under regional anaesthesia. Eur J Anaesthesiol 2009; 26: 643-7.

31. Rigamonti A, Scandroglio M, Minicucci F, Magrin S, Carozzo A, Casati A. A clinical evaluation of near-infrared cerebral oximetry in the awake patient to monitor cerebral perfusion during carotid endarterectomy. J Clin Anesth 2005; 17: 426-30.

32. Ritter JC, Green D, Slim H, Tiwari A, Brown J, Rashid H. The role of cerebral oximetry in combination with awake testing in patients undergoing carotid endarterectomy under local anaesthesia. Eur J Vasc Endovasc Surg 2011; 41: 599-605.

33. Samra SK, Dy EA, Welch $K$, Dorje P, Zelenock GB, Stanley JC. Evaluation of a cerebral oximeter as a monitor of cerebral ischemia during carotid endarterectomy. Anesthesiology 2000; 93: 964-70.

34. Sbarigia E, Schioppa A, Misuraca M, et al. Somatosensory evoked potentials versus locoregional anaesthesia in the monitoring of cerebral function during carotid artery surgery: preliminary results of a prospective study. Eur J Vasc Endovasc Surg 2001; 21: 413-6.

35. Silbert BS, Koumoundouros E, Davies MJ, Cronin KD. Comparison of the processed electroencephalogram and awake neurological assessment during carotid endarterectomy. Anaesth Intensive Care 1989; 17: 298-304.

36. Stoughton J, Nath RL, Abbott WM. Comparison of simultaneous electroencephalographic and mental status monitoring during carotid endarterectomy with regional anesthesia. J Vasc Surg 1998; 28: 1014-21.

37. Whiting $P$, Rutjes AW, Reitsma JB, Glas AS, Bossuyt PM, Kleijnen $J$. Sources of variation and bias in studies of diagnostic accuracy: a systematic review. Ann Intern Med 2004; 140: 189-202.

38. Pham B, Klassen TP, Lawson ML, Moher D. Language of publication restrictions in systematic reviews gave different results depending on whether the intervention was conventional or complementary. J Clin Epidemiol 2005; 58: 769-76.

39. Schunemann HJ, Oxman AD, Brozek J, et al.; GRADE Working Group. Grading quality of evidence and strength of recommendations for diagnostic tests and strategies. BMJ 2008; 336: 1106-10. 